\title{
The Emotional Psychology of Moral Panics: A Cognitive Neoassociationistic Perspective
}

\author{
Harry Huang*, ${ }^{\dagger}$, Sebastian Kane* \\ *These authors contributed equally to this manuscript. \\ $\dagger$ Direct correspondence to harry.q.huang@hotmail.com.
}

\begin{abstract}
Many moral panic scholars have noted a general failure to examine emotion and media effects on individuals in moral panic literature and have recommended a psychological approach to address this problem. We propose that cognitive neoassociation theory, and especially the associationistic aspect, can explain emotions and resulting actions generated by individuals in moral panics. We provide a theoretical framework for the psychological and emotional course of moral panics through cognitive neoassociation theory. We examine the specific case of businesses that were forced to rebrand from names containing "Isis," employing quantitative and qualitative methods to demonstrate the inadequacy of prevailing theories and the explanatory power of cognitive neoassociation theory. We conclude with some further directions for psychological research into moral panics.
\end{abstract}

\section{Introduction}

Moral panics are a mass social phenomenon in which a perceived social problem is blown out of proportion and transformed in the popular consciousness into an existential threat to the very fabric of society. Some are perennial themes, like youth violence, drug use or crime, while others, like the Satanic Panic in the late 1990s, are one-offs. In each case, a certain deviant segment of society is sought and molded into an evil, larger-than-life trope out to corrupt the youth, destroy Western civilization, or generally cause havoc and chaos, depending on the exact flavor of the moral panic. This folk devil serves to amplify fear, anger, and hostility and rile up the people. Of course, genuine concern about real social problems can exist, but the moral panic is distinguished by the element of irrationality and disproportionality, where the threat is grossly exaggerated (Critcher 2017).

The two main theories of the process of the moral panic are the elite-engineered model and the interest-group model. The elite-engineered model takes a cynical view of the moral panic, arguing that it is intentionally fomented by social elites for their own ends: distracting from other social problems or diverting attention from themselves, etc. The elite-engineered model understands the moral panic as primarily serving the interests of elites and as occurring in a top-down fashion, as the elites decide what they want and compel the media to foment the panic accordingly (Goode and Ben-Yehuda 2009, pp. 62-66). 
The interest-group model identifies a third group between the public and the elites consisting of various interest groups, professional organizations, and the media itself, which it asserts is largely responsible for moral panics. Unlike in the elite-engineered model, these groups do genuinely believe in the message of the moral panic and push out their message to a broader audience. In the interest-group model, the moral panic does start from a place of genuine concern but is still carefully orchestrated by civic society groups through the media, so it is still a top-down model of the moral panic (Goode and Ben-Yehuda 2009, pp. 67-69).

An unfortunate consequence of the Cohen's seminal 1972 sociological sketch of the moral panics is that the study of moral panics has remained firmly in the domain of sociology ever since, to the point that the field has neglected to examine the psychological factors in individuals that mediate media framing and public reaction and has built itself upon the "implicit supposition that the public are naively trusting of media" (Jewkes 2015, p. 100). In both the elite-engineered and interest group models, "collective beliefs [are] 'initiated from above' and [are] transmitted from claims-makers to the wider public" via the mass media, catalyzing the moral panic (Hier 2008, pp. 176-77). These models frame moral panics as wholly sociological in nature and neglect the agency of individuals in moral panic construction, instead treating them like gullible vessels who consume and believe mass media messaging uncritically. The assumption of the simple, gullible audience is an established critique of moral panic theory; some scholars even charge that "there is a built-in resistance [among moral panic scholars] to investigating media audiences empirically." (Critcher 2017) Academic discourse on moral panics has always treated "emotion as a black box," preferring instead broad sociological analysis that fails to engage with how the moral panic actually manifests in the emotions of individuals (Walby and Spencer 2011, p. 110). Walby and Spencer further assert that moral panic research has yet to address how "emotions [are] generated at the individual level" and how "emotions contribute to action" (Walby and Spencer 2011, p. 104). Falkof (2018) argues that even the "words that are used to describe [moral panics] - terms like repression, anxiety, even hysteria - point to the value of invoking a psychoanalytic register," rather than only a narrow sociological perspective (p. 9). Hier (2008) notes that the complex dynamics of moralization within a moral panic, and in turn, the role of emotions within moralization, have been largely neglected in moral panic research in favor of an overly narrow focus on the beliefs transmitted by the media. Angelides (2004) bemoans the prevailing social deterministic mode of analysis that ignores the moral panic's psychological roots. Pearson and Charman (2011) also recognizes the value of a psychological perspective, arguing that psychological analysis can "help explain public receptivity to moral panic discourse" (p. 294).

There is also the grassroots model, which does not place the media in the primary role. The grassroots model believes that although the media may appear to stir up a moral panic, media coverage reflects already existing public concern latent in society, and often occurs because of grassroots advocacy efforts (Goode and Ben-Yehuda 2009, pp. 55-62). However, the grassroots model also fails to psychologically treat with the moral panic, and fails to examine media effects on individuals.

Our paper represents a first step towards reconceptualizing the moral panic as at once a macroscopic sociological phenomenon and as the product of individual psychological processes. We assert that the psychological processes mediating the connection between media coverage and the emotions and acts of individuals are critical to a full understanding of the moral panic. We suggest that 
Berkowitz's cognitive neoassociation theory provides a convincing model for these psychological processes and explains many of the characteristics of a moral panic. We examine cognitive neoassociation theory in the context of moral panics involving media. The applicability of the theory to moral panics in which the media plays no role is out of scope. To demonstrate the value of Berkowitz's theory, we will examine the case of a moral panic involving businesses with names containing 'Isis' in the UK.

\section{Cognitive Neoassociation Theory}

The origins of cognitive neoassociation theory lie in the frustration-aggression hypothesis. Dollard et al. (1939) succinctly proposed that "aggression is always a consequence of frustration," and that frustration necessarily results in aggression (p. 1). They defined frustration as specifically "an interference with the occurrence of an instigated goal-response" (Dollard et al. 1939, p. 7). In other words, if an individual is actively seeking to attain a certain goal, then any impediment that disrupts progress towards the goal is a frustration. For example, a toddler may kick and scream as they are forcibly put to bed, having been thwarted in their goal of staying awake, or an employee may engage in verbal aggression if denied a raise by their employer.

Since Dollard et al.'s seminal work, much criticism has been leveled at their ambitious claim that all frustration results in instigation to aggression and much research has been devoted to discovering further relevant factors in the generation of the instigation to aggression from a frustration (Breuer and Elson 2017). Berkowitz (1989), taking into account these criticisms, formulated cognitive neoassociation theory, which has received strong empirical support and general acceptance (Berkowitz 1990). He suggested that aggression was caused by aversive events via negative affect. The concept of aversive events expands beyond Dollard et al.'s narrow conception of frustration to include any type of unpleasantness or annoyances, like inclement weather, physical pain, or socially unpleasant experiences (Berkowitz 2008). Negative affect is generated in greater or lesser strength from the aversive event depending on various beliefs and attributions, e.g. whether or not the aversive event is perceived as justified, whether it was expected, etc.. Negative affect therefore incorporates another common line of attack against the frustration-aggression hypothesis about the importance of beliefs and attributions. For example, if a frustration is believed to be justified or in line with social rules, then the instigation to aggression is reduced.

Berkowitz (1962) examined the relationship between the generation of fear and anger, building off of Miller (1941)'s suggestion that multiple instigations are produced by frustrations. Berkowitz suggested that all frustrations produce a mix of fear and anger, and that in some cases, fear may even predominate anger. For example, WWII air raid survivors reacted nearly exclusively with fear in the moment, contradicting the frustration-aggression theory in its most basic form. Proceeding from this case, Berkowitz suggested that situations in which fear predominated over anger occurred when the frustration was very serious, since "as the intensity of [a] noxious stimulation increases...fear rises more rapidly in intensity than does anger," or when the individual had little ability to strike back at the frustrating agent and prevent further noxious stimulation (pp. 44-45). Berkowitz weaved this idea into cognitive neoassociation theory, postulating that the initial subconscious phase involved a branching out into either rudimentary fear or rudimentary anger via fight-or-flight related tendencies (Berkowitz 2011). 
Importantly, Berkowitz viewed instigation to flight and instigation to aggression as a spectrum, produced in greater or lesser relative amounts depending on the circumstances.

After negative affect is generated, it is then transformed into a primordial form of anger or fear by a complex of subconscious factors, and sometimes further refined through conscious controlled processing. The subconscious factors primarily consist of a network of associations, which link negative affect with a variety of negative and aggressive or fearful feelings, memories, and physiological reactions. Collins and Loftus (1975) indicate that this associative network is essentially Quillian (1967)'s theory of spreading-activation networks in semantic processing. In short, various nodes representing semantic concepts are linked together. A node is activated when the concept enters into conscious thought, but the spreading-activation process is a form of automatic processing. Related nodes are in turn activated, spreading out through the network. However, the activation strength decays with each link that is crossed, decaying more when the link is weaker. The strength of each link represents the strength of the association in the mind of an individual between the two concepts. Once a semantic memory search is completed, all the nodes which it has passed through are considered to be "primed." For some amount of time, these primed nodes, and therefore related nodes, are easier to access. In the case of cognitive neoassociation theory, if a concept is linked to aggression or flight-related nodes, aggressive or flight-related thoughts and acts will be easier to access, causing changes in emotion and physiological reactions (Berkowitz 1984).

Although concepts have natural semantic links, the strength of links are also affected by individual factors and experiences. The strength of these networks may also reflect personality factors (Bushman 1996). Critically, links become stronger the more they are used, and new links can be created when nodes are activated simultaneously (Anderson and Bushman 2002). For example, an individual who recently read an article on athletically-inclined writers might have an unusually strong link between "writing" and "sports." Or, an individual who witnessed an act of violence committed with a pumpkin may now have a link between "pumpkin" and various aggressive nodes, since the "pumpkin" node and aggressive nodes were simultaneously activated by that event. In that sense, certain concepts can take on aggressive or flight-related meanings and serve as cues that cause or intensify aggression or flight. For example, Josephon (1982) found that schoolchildren were more aggressive in a floor hockey game when an observer used a walkie-talkie, after they had built up an association between walkie-talkies and violence through watching a violent scene in a TV show in which a walkie-talkie appeared (pp. 89-159). Therefore, associative networks, and thus the ways in which aggression or flight tendencies are generated, can be modified by an individual's experiences.

After automatic processing comes controlled processing. After rudimentary emotion is generated by the subconscious associative network, certain conscious cognitions may further modify the instigation to action. An individual consciously reflecting on their emotions may, for example, recognize that acts of aggression would be socially unacceptable, or recognize that their anger is irrational, thereby impeding the instigation to aggression. Cognitions, however, can also intensify instigations to action. Importantly, unlike subconscious processing, cognitions are not always present in the cognitive neoassociationistic process. Certain acts of aggression are indeed spontaneous, impulsive acts that do not involve higher-order cognitive processes (Berkowitz 2011). 
A more recent development in the field is the General Aggression Model, which synthesizes several models of aggression, including cognitive neoassociation theory. Although the General Aggression Model has achieved general acceptance in the field of aggression research, we did not feel that the use of the full General Aggression Model would contribute. The General Aggression Model proposes several different pathways for aggression to be generated, each descending from a separate model (Anderson and Bushman 2002). In the specific case of moral panics, those theories are clearly inapplicable, and those alternate pathways implausible. Therefore, we see no benefit in using the General Aggression Model over cognitive neoassociation theory in the case of moral panics.

\section{The Psychology of Moral Panics}

We argue that a moral panic is partially the sum of individual psychological processes iterated en masse. Theories of individual psychology, like cognitive neoassociation theory, can be used to understand a sociological phenomenon like a moral panic, since a moral panic is an emergent phenomenon of individual psychologies. We therefore examine how aspects of a moral panic emerge in individuals, assuming that certain macroscopic effects characteristic of moral panics can be loosely understood as at least in some part an aggregation of these individual effects.

The moral panic always begins with a perceived threat to the social order (Goode and Ben-Yehuda 1994). The moral panic draws up a line between upstanding citizens defending the social order, and the nebulous folk devils who threaten it. The folk devil is exaggerated into an existential threat that, left unchecked, will raze society and completely reshape it in a dystopian mold: fever dreams of an Islamic caliphate and sharia law in the West, or hysteria about Satanists destroying the Judeo-Christian fiber of society. Therefore, just as a physical assault is an aversive event that generates fear and anger and related action tendencies, the folk devil assaults the collective body of society, which serves as an aversive event for the members of society.

For most moral panics, the media serves as the gatekeeper and interpreter of information. Beyond the editorial prerogative to select what information is disseminated, the power of media framing and commentary defines the socially appropriate reaction. Therefore, the interpretive work of assessing the threat of an aversive event and applying various beliefs required to generate negative affect from the aversive event is partially done by the media. Some authors even conceptualize the moral panic as a form of moral regulation and deliberate fear mongering calculated to provoke a certain societal reaction; in essence, they view the creation and calibration of negative affect as intentional (Critcher 2009). This process of interpretation is known as threat construction, folk devil creation, or moralization. In other words, the media passes subjective judgement on the aversive event for the public; in the case of a moral panic, this subjective judgement outrageously exaggerates the threat, thereby significantly increasing negative affect as well. Although individuals may engage critically with media coverage rather than accepting it in its entirety uncritically, as the primary source of information about the folk devil, the media undoubtedly still has a potent influence. Therefore, the degree to which the folk devil is typified, exaggerated, and stereotyped affects the magnitude of the negative affect experienced by individuals, which in turn regulates the strength of the instigation to action, ceteris paribus. The more hysterical and sensational the media, the stronger negative affect and the more intense the moral panic. 
This stage also creates the characteristic disproportionality of moral panics. The media is uniquely positioned to divorce the magnitude of negative affect from the magnitude of the aversive event through exaggerating the facts of the aversive event and careful framing, thereby generating disproportionate concern.

Fear and anger are integral aspects of a moral panic (Krinsky 2008, p. 1). The widespread perception of a pressing, existential threat to the social order necessarily produces a wave of mass fear and anger. "Fear and anger ... have distinct behavioral and psychological correlates" and "are respectively related to avoidance and approach motivations," and affect assessments of risk, which is useful "in determining [a terrorist attack's] overall effect on national discussions of policy" (Baucum and John 2019). Baucum and John (2019) specifically found that after the Orlando terrorist attack, fear decreased much more rapidly than anger over time, while anger increased with spatial distance from Orlando. Ahmed et al. (2018) analyzed the Twitter response to the swine flu outbreak of 2009 and the Ebola outbreak of 2014 and argued the exaggerated fear present on many of the tweets could be evidence of a moral panic. They found that of tweets which expressed emotional themes, about 6.7 percent and 15 percent for swine flu and Ebola, respectively, were anger-based. Fear predominated: 69 percent and 49 percent of emotional tweets relating to swine flu and Ebola, respectively, expressed fear. Understanding the relative extent of fear and anger in a moral panic offers insight into the specific processes of the moral panic. Berkowitz's integration of fear and anger through cognitive neoassociation theory can theoretically account for the gradient of fear and anger that appears in moral panics. We advance that the relative degree of fear and anger present in moral panics can be explained by the associative networks of individual participants, which is in turn governed by a host of factors, such as media framing and personality traits. Primitive fight and flight tendencies are generated in varying relative amounts as negative affect undergoes automatic processing. As mentioned previously, Berkowitz suggested that fear generally predominates anger when the individual is unable to retaliate against the frustrating agent, or when the frustration is especially strong (Berkowitz 1962, p. 44). While these moral panics surrounding disease seem to confirm Berkowitz's conjecture, the implications of the possible existence of moral panics dominated by fear are unclear. Our cognitive neoassociation analysis of moral panics illustrates a need for further research into the emotions of fear and anger and the construction of their associative networks and how the relative degree of fear and anger affects the course of the moral panic.

We theorize that consuming mass media establishes associative networks that cause the hostility characteristic of moral panics. In moral panics, the media demonizes the deviant group and constructs a morality play of good and evil, creating an exaggerated folk devil image of the deviant group (Critcher 2017). This stereotyping falls into the hostility criterion of the attributional model (Goode and Ben-Yehuda 2009, p. 38). In spinning ISIS into a folk devil, the Daily Mail used a sensationalist conflict frame, making use of loaded, conflict-based language such as "terror," "militant," and "fighter" (Boyle and Mower 2018). Richardson et al. (1991) observed similar media framing in the moral panic around Satanism in the late 20th century. The news media "depicted [Satanism] as a thoroughly deviant phenomenon;" a widespread, morally corrupt, criminal movement that threatened the social order "physically, emotionally, morally, and spiritually" and symbolized the "decline of the family and [the] loss of faith in government and in God" (Rowe and Cavender 1991, p. 273). Notably, during the deviancy amplification spiral of the Satanic panic, more and more lurid articles on supposed Satan-worshiping criminals and pedophiles running suburban daycare centers and raping, kidnapping, and killing helpless 
children were published (Hughes 2017). Hughes (2017) found a media frenzy over trials of alleged abusers and interviews of alleged abuse victims, marked by news stories growing progressively more far-fetched. They argued that the news media constructed a "hyperreality" in which pedophilic Satanists were lurking in every shadow, disguised as unassuming daycare workers; this hyperreality was taken at face value by the general public. Mass paranoia set in, and accusations of Satanic ritual abuse exploded. This sensational conflicted-based framing appears fairly consistent across moral panics, and also emerged in the Sydney "ethnic gang" moral panic from 1998-2000. The media vilified the gangs and fixated on their violence, framing them as foreign, criminal, and a threat to law and order - a broader symptom of deviant, uncontrollable, ethnic youth (Poynting, Noble, and Tabar 2001). We theorize that media framing of the folk devil generates spreading-activation networks. The sensationalist conflict-framing employed by the media nodally links the object of the moral panic with various fight and flight concepts in the mind of the viewer when nodes are simultaneously activated. These associations are strengthened and concepts in the network become more accessible during the deviancy amplification spiral as sensational media coverage proliferates. As previously mentioned, Josephon (1982) found that neutral items could be used to prime aggressive nodes if they were previously displayed in aggressive concepts, consistent with the link-building ideas of spreading-activation theory in the cognitive neoassociation model. We suggest that the media builds up associations between aspects of the folk devil and anger and fear nodes, just as in Josephon (1982)'s experiment, thereby laying the groundwork for the emotions and actions of the moral panic.

Obviously, hostility in moral panics is not elicited only when the folk devil itself is encountered. Encounters with genuine Satan-worshipping baby-killers, or foreign Casanovas looking to seduce and enslave white women are few and far between, since the folk devil itself is only an exaggerated figment of the collective social imagination. Instead, individuals with some stimulus qualities associated with the folk devil will elicit fight or flight responses, i.e. childcare workers in the Satanic Panic or various minorities in white slavery moral panics. These stimulus qualities are situational cues that stimulate certain nodes and cause or intensify fight or flight reactions. For example, to a racist, African-Americans might serve as aggressive situational cues, since via links created by stereotypes, they are connected to aggressive nodes (Burgess et al. 2011). Indeed, cues may be even more indirect. Devine (1989) found that words which themselves carried no natural aggressive meaning, such as "welfare," "slavery," "ghetto," but that were associated with stereotypes of African-Americans, were still able to elicit hostility. Extensive research has found evidence for this "priming effect" that situational cues have (Berkowitz 1984). In the case of ISIS coverage by the Daily Mail, readers may now have links in their associative networks between ISIS and "terror," "militant," "fighter," anger and fear related nodes, and not necessarily naturally aggressive but conceptually-related nodes like "black flag" or "Arabic." For the Satanic Panic, the media may have constructed a spreading-activation network in which "children" and "daycares" were perhaps linked to "Satanists," "cultists," "murderers," fear and anger related nodes, and behaviors supposedly indicative of Satanism. These associative networks may have contributed to accusations of Satanic activity. A childcare worker may serve as a situational cue that activates a node related to the Satanic folk devil, triggering a cascading effect along associative pathways, ultimately generating negative affect and then hostility. Similar spreading-activation networks may have been constructed for "ethnic gangs" in Sydney; "gangs" might be linked to "ethnic," "violence," "foreign," "criminal," along with fear and anger related nodes. Importantly, a hostile reaction can occur whenever there is a situational cue that causes the activation of any one of these nodes, not only when all are 
present. Therefore, in the course of a moral panic, instigations to action will be automatically generated whenever individuals encounter situational cues linked to the folk devil.

This aspect of cognitive neoassociation theory is able to explain the irrational accusations and the sort of "paranoia" that crops up in moral panics. Moral panics are characterized by an exaggerated, stylized folk devil perceived as threatening the social order, which attracts public hostility (Critcher 2017). By consuming media that exaggerates the threat of the folk devil, individuals develop an inaccurate perception of the world and create a schema that excessively favors explaining events in relation to the folk devil, as opposed to a schema based on a rational assessment of the threat of the folk devil, which does not unduly favor explanations of events involving the folk devil. Clinical paranoia also causes individuals to build up schemas, known as delusions, that are used as interpretative frames that cause them to perceive nefarious signs in mundane daily occurrences (Vinogradov, King, and Huberman 1992). These delusions impart nefarious meanings to neutral events and the corresponding spreading-activation network nodes through an associative network. Over time, as the delusion is continually used, the associations become stronger and the paranoia therefore intensifies. Crucially, Vinogradov, King, and Huberman (1992) theorized that paranoia is not a binary, but instead lies on a spectrum determined by continuous variables describing characteristics of the associative network. Therefore, even if paranoia in moral panics does not rise to a clinical level, there may still be an increase in paranoid behaviors and the level of paranoia. We theorize that moral panics impose a schema on members of society that promotes certain paranoid behaviors. Many scholars have specifically noted the presence of public paranoia in the moral panics they studied (Moore 2004; Gilman 2010; Shafir and Schairer 2013, p. 15). South Africa's Satanic Panic is especially emblematic of the paranoid thinking which pervades moral panics. Despite the lack of evidence for the widespread Satanic activity alleged by the media, frenzied members of the public, in the typical fashion of moral panics, lashed out. Rebellious adolescents were declared Satanists, alleged Satanists were arrested, and unsubstantiated rumors, like a police captain claiming that nineteen babies were specially bred for grotesque Satanic sacrifice, or a self-professed "Satan-hunter" asserting that there were over 200,000 South African Satanists, or some ten percent of the white population, entered into the national conversation (Falkof 2012). Falkof (2012) described an atmosphere in the early 1990s in South Africa in which "police were primed to see Satanists lurking behind every unusual violent crime."

Instigations to aggression generated in the preceding, unconscious, manner are generally incompatible with the drive to maintain a positive self-perception, since instigations to action originating in the unconscious domain are usually irrational. Without further psychological processes, the individual would then perceive themselves as prone to irrational aggression, conflicting with the drive to maintain a positive self-perception. Baumeister, Dale, and Sommer (1998) provides evidence that Freudian defense mechanisms serve to reconcile this contradiction and maintain a positive self-perception. Definitionally, a moral panic is an irrationally excessive reaction to a perceived threat, yet individuals fail to consciously recognize their behavior as irrational. Therefore, they must necessarily employ the defense mechanism of rationalization. Frost, Ko, and James (2007) found that individual differences in the strength of justification mechanisms, which facilitate rationalization, affect the expression of aggression. If an individual lacks the ability to effectively justify their aggressive tendencies originating in the unconscious, they will consciously inhibit aggression, although they may still engage in spontaneous, impulsive acts of aggression not involving conscious processing. On the other hand, if an individual has 
strong justification mechanisms, they may aggress more openly, if they perceive themselves as aggressive, or aggress in more socially acceptable ways, if they perceive themselves not to be aggressive. Frost, Ko, and James (2007) found strong empirical evidence for this channeling hypothesis. Berkowitz and Troccoli (1990) found that when individuals were forced to consciously consider their feelings, they modified the actions instigated by these feelings to be more in line with social rules. They proposed that controlled processing caused individuals to consider social and situational factors. Since social rules restrain aggression that an individual can justify less so than unjustified aggression, in providing a justification, rationalization allows individuals to aggress more freely without perceiving themselves to be violating social norms. The power of a moral panic, as a widespread sociological phenomenon, to actually modify social standards and reduce social sanctions against aggression against the folk devil may also contribute through the channeling hypothesis to aggression, by expanding the range of socially acceptable forms of aggression. Bandura (1999) suggested that individuals are able to engage in behaviors that contradict their moral standards through the process of moral justification, a form of rationalization in which an individual reframes their behavior as serving a moral purpose. For example, individuals may justify killing in wars through just war theory. By focusing on this new moral imperative to aggress, individuals sidestep their personal morality. Moral justification is especially relevant in the case of moral panics, which are characterized by the moralization of the folk devil and the construction of the conflict between good society and the folk devil as a struggle between irreconcilable forces of good and evil. Therefore, we theorize that rationalization prevents aggression from being restrained by social norms at the conscious stage of the cognitive neoassociationistic process.

Rationalization may also occur post-hoc in cases of spontaneous aggression, which would not affect the strength of the aggression, although it might ease further acts of aggression. Examining when conscious processes are involved in the generation of aggression as opposed to when aggression is spontaneous is out of scope. We are unsure if aggression combined with pre-hoc rationalization is stronger than spontaneous aggression.

\section{The Case of the Businesses}

\section{Deficiencies in Moral Panic Theory}

To illustrate the applicability of cognitive neoassociation theory to moral panics, we will analyze a peculiar phenomenon related to the entry of ISIS into the UK national conversation. Many businesses around the UK used to have 'Isis' in their name (e.g., Isis Boutique, Isis Salon), often in reference to the Egyptian goddess or the River Isis in Oxford. After the rise of ISIS, these businesses began to face harassment and vandalism because of their names. The Isis Beauty Academy experienced a 50\% drop in student enrollment and a concerted telephone harassment campaign; one student even suspected that it was a front for ISIS (Tobitt 2015). The Isis Salon faced a barrage of threats that disconcerted employees to the point that they had to be escorted home after late-night shifts (Shammas 2016). In some cases, these businesses were directly attacked for their name, and termed disrespectful or insensitive. Under pressure, many ended up changing their names. 
Obviously, this phenomenon must have been caused by the entry of ISIS into the UK national conversation. However, the pressure on these businesses was not stoked or instigated by the media; in fact, nearly all media reports on the phenomenon castigated the perpetrators. Yet, the two primary moral panic theories - the elite-engineered and interest-group theories - frame the media as the instigators of the moral panic, or at least the willing tools of other instigators, who define the object of the moral panic and direct public hostility towards it. Garland (2008) calls the media the "prime mover" of moral panics. These theories therefore fail to adequately explain all the facets of the moral panic. In both theories, the folk devil as understood by the people is the same as the folk devil the media defines. The media therefore exerts strong control over the course of the moral panic and directs moral outrage towards targets it chooses. Indeed in some cases, this may be true; in an extreme case, violent vigilante attacks occurred against people whose photos were published by the British media as part of a "name and shame" campaign against child sex offenders (Angelides 2004). However, this case of the business names involves a gap between media coverage and individual conceptions of the folk devil. The potential for the redirection of emotions by individuals remains unexplored by moral panic literature, which rests on the implicit assumption that individuals act exactly as told. The elite-engineered model goes as far as to characterize the public as "puppets or marionettes being pulled this way or that by strings manipulated from above" (Goode and Ben-Yahuda 2009). Therefore, individuals pursuing (semi)-independent courses of action presents a challenge to the traditional theories of moral panics and highlights the individual psychological element of moral panics. Through Berkowitz's cognitive neoassociation theory, we can account for this phenomenon as a result of individual psychological processes.

\section{Name Changes as a Moral Panic}

The phenomenon surrounding these businesses bears the hallmarks of a moral panic. Although Cohen's processual model is the original moral panic model, we will examine this phenomenon through Goode and Ben-Yahuda's attributional model, which is less structurally rigid and more appropriate for this case. Goode and Ben-Yahuda (2009) identify five defining characteristics of a moral panic: concern, hostility, consensus, disproportionality, and volatility.

- Concern is the presence of the object of the moral panic in the national conversation and a sense of anxiety about the object of the moral panic as a severe threat to the social order.

- Hostility is antipathy towards a deviant group identified as responsible for the object of the moral panic. Demonization may then reinforce the dichotomy between the deviant group and the rest of society.

- Consensus requires that concern be widespread and be shared by at least a certain subset of society, although not necessarily a majority.

- Disproportionality is the presence of irrationally excessive concern relative to the actual scale of the threat, which is often accompanied by a misperception of the actual scale of the threat.

- Volatility is the tendency for concern about the object of a moral panic to fluctuate in intensity, climbing up to a fever pitch rapidly and dissipating quickly. However, certain types of panics, such as illegal drug use or child abuse, may become "routinized" and periodically reoccur.

Some of the data we use to demonstrate these five attributes are concerned about terrorism in general, or Islamist terrorism in general. However, for the time period in question in the UK, concern about Islamist terrorism has far exceeded concern about other forms of terrorism, and in turn, concern 
about ISIS has far exceeded concern about other minor Islamist terrorist groups. Therefore, we take concern about terrorism or Islamist terrorism in general to be largely equivalent to concern about ISIS specifically.

\section{Concern:}

The phenomenon of the business names is obviously derivative of a larger preoccupation with terrorism, and especially ISIS. The root object of this moral panic attracting public concern, therefore, is ISIS. During this time period, news about ISIS filled British airwaves and persisted in the national conversation. From June 10, 2014 to December 10, 2014, the Daily Mail, Great Britain's second largest newspaper at the time, published 1,001 ISIS-related articles: on average, over five a day, generally applying a conflict frame (Boyle and Mower 2018). Stephanie Kelley, a columnist at The Oxion Globalist, even asserted that the fearmongering of the Daily Mail was so extreme that it "might as well sign itself up to be a wing of ISIS's PR team" (Kelley 2015). In the immediate aftermath of the 2015 Tunisian beach attacks, then-Prime Minister David Cameron declared that ISIS posed an "existential threat to the British way of life" (Cameron 2015). In 2016, a majority of the public supported British military intervention in the Middle East to completely destroy ISIS, and 43\% felt that the British government was taking inadequate steps to combat Islamic extremism (Smith 2016).

\section{Hostility:}

The construction of these businesses as a threat fits into the pattern of reactions against in-group deviants. In drawing up battlelines against an out-group threat, the in-group must re-negotiate its own identity to promote solidarity against the enemy (Chernobrov 2018). In-group members are forced to coalesce more tightly around a set of values and behaviors. As the standards for in-group belonging tighten, members "either must get completely along with, or completely repel" each other (Simmel [1908] 1964, 92-93). Since the threat of the external enemy creates "a moral order constructed out of the conflict of manichean, polar opposites - a struggle of good and evil," anyone who fails to meet the exacting standards of the in-group must therefore be aligned with the enemy: a traitor, a deviant of suspect allegiance (Thornham and Purvis 2005). Just as ordinary British Muslims, deviating culturally from the mainstream, were vilified and suspected of being disloyal, these businesses became deviant in-group members, perceived to be aligned with the external threat by being insensitive to victims of ISIS, or supposedly even directly cooperating with ISIS (Chernobrov 2018). They were perceived as a "fifth column," implicitly supporting the out-group enemy by failing to follow the new rules of the in-group. They were ostracized and framed as threats to the moral order of the in-group. As clear battle lines were drawn up against the enemy, these businesses were identified with the Other, thereby attracting some of the aggression directed towards the Other.

According to CBS News, "not long after ISIS first started burning itself into the consciousness of people everywhere, businesses that had Isis in their names started feeling the heat and either voluntarily or under pressure began considering alternatives" (Kennedy 2014). The harassment faced by businesses ranged from snide comments up to accusations of links to terrorism, and ironically, threats of violence. A Manchester spirituality store, an Essex beauty salon, and a Surrey beauty academy were among the businesses facing abuse due to accusations of being linked with ISIS; employees at the Essex salon were even escorted home at night for a time out of concern for their safety (Scapens 2014; Shammas 2016; Tobitt 2015). The Surrey beauty academy specifically noted "receiving phone calls from some people 
who've been rude and abusive accusing us of being racist among other things," and were even suspected of being "an undercover grooming place for Islamic extremists" (Tobitt 2015). The owner of a UK clothing shop reported receiving a letter bomb threat over their name (Kennedy 2014). A Levenshulme cafe formerly called 'Isis' was warned by police that their name might put them in danger, and they ultimately decided to rebrand (Glendinning 2014).

Beyond harassment, other businesses noted a marked drop in sales that they attributed to their name; the Surrey beauty academy had a 50\% drop in sales; many businesses also noted a sense of unease among their customers (Newsroom 2017; “"Brand Suicide”: Companies Sharing Name with ISIS Forced to Rebrand" 2014) Although we did not find any documented instances of coordinated, organized boycotts of these businesses, these drop in sales are still reflective of hostility. In choosing not to patronize these businesses, customers reinforce the moral barriers isolating the deviant group from respectable society. Even if they avoid these businesses solely out of rational self-interest, i.e. not wanting to be seen in the store or with products from the store, they still have recognized that a deviant group has been socially constructed and to associate with the deviant group would incur social consequences, which reinforces the divide between the deviant group and respectable society. Therefore, these drops in sales do reflect societal hostility.

The businesses in our case differ from Goode and Ben-Yehuda's conceptualization in a small nuance: they are perceived as being aligned with the folk devil, rather than as the folk devil. Therefore, unlike with ISIS, no stereotypical trope about these businesses emerged into the social consciousness, although they did face hostility in other ways that may resemble a sort of "proto-demonization". This nuance results from the psychological transfer of emotion from the terrorist group ISIS to these businesses, since stereotyping, demonization and stylization only occur towards the former.

Walsh (2016) asserts that terrorism is especially easy to construct as a folk devil, since, atypically for the objects of moral panics, the terrorist wants themselves to be feared and demonized, and wants a moral panic. The modus operandi of the terrorist is the propaganda of the deed: violent acts to invigorate supporters and provoke an overwhelming, irrationally angry reaction from state opponents that will expose the brutality and injustice of the state. A moral panic, in which society enters into a state of total mobilization against an imagined existential threat, tends toward the draconian, disproportionately harsh response that terrorists seek. Terrorists also benefit from a symbiotic relationship with mass media. Publicity serves the ends of the terrorists, and for the media, sensational and lurid stories sell newspapers. Terrorists recognize how they can benefit from a moral panic, and so actively act to facilitate its creation through the propaganda of the deed. Walsh notes that radical Islamist terrorist groups, and al-Qaeda especially, from which ISIS originated, have pursued an active strategy of provocation, hoping to invite unnecessarily and irrationally harsh military reactions and reap the benefits of a moral panic. Indeed, American military actions and atrocities in the Middle East and rising Islamophobia at home played into al-Qaeda's goal to frame the conflict as a divinely-ordained holy war against the Jews and Christians of Western societies which were fundamentally incompatible with and hostile towards Islam.

Like other terrorist groups, ISIS has easily attracted the hostility it has sought. Hamed (2017) noted that "[headlines] about the atrocities committed by ISIS [are] instilling more fear into the Western citizens making it hard to break down the moral panic which has come out of the ISIS coverage" (Hamed 
2017, p. 99). As mentioned in the concern section, ISIS has attracted hyperbolic denouncements and a veritable avalanche of sensational media coverage in the UK. Indeed, fear and hostility towards ISIS reached such a fever pitch to spill over into numerous incidents of Islamophobia against British Muslims (Pargeter 2015). The early 2000s in the UK were characterized by "a hysterical Islamophobia since September 11th, Afghanistan, Bali and Mombasa, [which] caricatures all Muslims as fatwa fanatics and enemies of the West," which has only continued unabated as the War on Terror continues after the rise of ISIS (Amin 2003 p. 460). Widespread support for interventionist military policies against ISIS, as detailed in the consensus and volatility sections, also evince hostility against ISIS.

\section{Consensus:}

Evidence of heightened societal concern about the threat of ISIS and widespread hostility towards businesses with names containing 'Isis' is sufficient to fulfill the consensus criterion. While consensus around the perceived threat of ISIS does not alone satisfy this criterion, it is consistent with widespread recognition of an undesirable deviant group: businesses with names containing "Isis." Pew found that ISIS was the top concern of the British public, with 66\% in Spring 2015 and 70\% in Spring 2017 answering that they were very concerned about the threat of ISIS (Carle 2015, p. 4; Poushter and Manevich 2017, p. 5). As ISIS rose to prominence throughout 2014, British public support from early August to early October for RAF air strikes against ISIS grew steadily from 37\% to 58\% (de Waal 2014). A survey conducted in July 2016 found that approximately 57\% of Britons believed the international community should seek to get rid of ISIS using military force if necessary (Smith 2016). Throughout the first half of the 2010s, ISIS was a prominent feature of the UK national conversation.

Although there is no pertinent public opinion polling, through Companies House (https://find-and-update.company-information.service.gov.uk/), the UK national register of limited companies, we found almost 80 businesses who rebranded from a name containing 'Isis' between January 5th, 2014 and December 17th, 2016 in just the UK. From news reports, there appears to be many more cases across the Anglosphere. It is theoretically possible that some businesses rebranded of their own volition, without facing pressure. However, many businesses expressed strong initial reluctance to rebrand, citing personal attachment to the name and cost concerns. Isis Recruitment waited for 10 months to change their name, finally spending 2 weeks and 1000 pounds sterling on rebranding, and the owner of an Essex salon declared that rebranding had cost them an "absolute fortune" (Sullivan 2014; Express 2016). The Harborough salon waited two years, before they finally gave in (Newsroom 2017). The Manchester shop felt that rebranding would give the impression that the business was struggling (Scapens 2014). As previously established, some businesses were financially affected due to their perceived association with ISIS. We believe it is reasonable to assume that the primary motivations of such rebrands are financial concerns and hostility experienced by these businesses. As such, we think it highly unlikely that businesses would rebrand absent external pressure. Therefore, the large number of businesses that rebranded indicates that pressure against these businesses was a widespread phenomenon, not isolated incidents. Furthermore, it is likely that the expectation of pressure or lost sales, which would vary with the prominence of ISIS in the national conversation and the degree of hostility against it, was at least a factor for all businesses.

This phenomenon was widespread and was observed across the United Kingdom. Among many others scattered across the UK, some businesses forced to rebrand due to public hostility were from 
Worcestershire, Surrey, Manchester, Essex, Oxfordshire, and Leicestershire (Kennedy 2014; Tobitt 2015; Glendinning 2014; Dare and Walker 2016; Scroll Staff 2016; Newsroom 2017).

\section{Disproportionality:}

Of the five points of the attributional model, disproportionality is by far the most bitterly contested. Critics assert that assessing disproportionality requires subjective judgement involving arbitrary normative standards, rendering the whole concept relative and therefore meaningless (Hier 2008). Goode and Ben-Yehuda (2009) counter that some claims can be proven objectively wrong and assert that disproportionality may also manifest indirectly as unfounded rumors, demonstrably false statistical claims, a lack of attention to similar and equally, if not more severe issues, and a decoupling of media attention from the severity of the issue. We believe that in the case of ISIS and Islamist terrorism, the sheer gulf between public concern and the actual impact of terrorism and the relative attention, or lack thereof, paid to other pressing issues satisfies the disproportionality criterion.

From 2010 to 2017, there were just 49 deaths in the UK from all types of terrorism (Islamist, Northern Ireland conflict, far-right): an average of about six a year (Kirk 2017). In contrast, seven people died from a foreign body in the larynx and 12 people died from infected amputation stumps in England and Wales in 2019 (Office for National Statistics 2020). Yet, in 2016, 12\% of the British public believed that there was a high chance that they or a friend or family member would be a victim of a terrorist attack (Smith 2016). In Spring 2017, 33\% listed terrorism as one of the two biggest issues facing the UK, greater than every other issue except "health and social security," at 34\%, and the British public also named ISIS the top threat to the UK. (European Commission 2017; Poushter and Manevich 2017). By December 2017, ISIS was down to just $2 \%$ of its peak territory (Tomlinson 2017), yet some 65\% Britons expected a major terrorist attack in their country in 2018, the highest of any country surveyed (Bulman 2018). There were no major terrorist attacks in the UK in 2018. In the same year, terrorism was ranked as the 4th highest concern of the British public, above the environment, housing, trade, crime, jobs, and immigration and another survey reported that $16 \%$ of respondents had avoided travel to a part of the UK out of fear of terrorism (Bulman 2018).

The fervent backlash against these businesses is patently disproportionate. Considering the complete lack of a threat, the reaction against these businesses is necessarily irrational and disproportionate.

\section{Volatility:}

Goode and Ben-Yehuda (2009) suggest that as long as the "intensity of [a concern], both locally and society-wide, waxes and wanes over time," then it fulfills the volatility criterion (Goode and Ben-Yehuda 2009, p. 43). Therefore, a concern may persist and embed itself as a fixture of society, at times fading into the background and at times returning to the quintessential hysteria of the moral panic.

In April 2013, ISIS renamed itself to ad-Dawlah al-Islāmiyah fì 'l- 'Irāq wa-sh-Shām, translated as either the Islamic State of Iraq and Syria (ISIS) or the Islamic State of Iraq and the Levant (ISIL) (Spencer 2015). Not long after, ISIS suddenly exploded onto the front pages of Western media. The Daily Mail first mentioned ISIS in an article on September 13th, 2013, labeling it as just a faction of Al-Qaeda (Enoch 2013). Then, from June 10, 2014 to December 10, 2014, the Daily Mail published an unbelievable 
1,001 articles on ISIS, an average of over five per day (Boyle and Mower 2018). Although ISIS did indeed make major territorial gains in 2014, it is simply stupendous that in a few months, ISIS, once just one of the indistinct mass of Middle Eastern terrorist groups, turned into the single-minded obsession of the Daily Mail and the British public.

Indeed, much of the jump in public concern about ISIS occurred in the last months of 2014. In a mid-August poll, 48\% expressed support for recalling Parliament from its recess to discuss the situation in Iraq; the same poll a week later found an astounding 10\% jump in support (YouGov 2015). From August to early October, support for committing British and American ground troops against ISIS shot up 12\% and support for RAF airstrikes went up 17\% (YouGov 2015).

Walsh (2016) notes the inherent volatility of concern about terrorism, stating that with the advent of the 24-hour news cycle, society has been doused with a pervasive, latent, anxiety about terrorism, ready to erupt into a moral panic at any moment (Walsh 2016). Indeed, unpredictable, highly disruptive terrorist attacks serve as sparks that cause an explosion of fear mongering, lurid reporting that restarts the moral panic around terrorism. Therefore, the nature of terrorism lends itself well to creating especially volatile moral panics.

Figure 1 provides a visual indication of volatility. It shows Google Trends data on searches for ISIS and data on the number of business name changes. The specific methods of data collection are detailed in Methods. The Google Trends data is characterized by a multitude of thin peaks. Most of these peaks represent a flurry of media coverage in the immediate aftermath of a major terrorist attack, driving public concern, which fades away rapidly as the media moves on not long after. Two clear Google Trends peaks are apparent at around the 20th and 50th two weeks periods, which are around the same time as the prominent ISIS beheadings in mid-to-late 2014 and the November 2015 Paris attacks, respectively. Two corresponding peaks are visually apparent in the name change data. The visual appearance of the graphs capture the volatility of this moral panic empirically. 


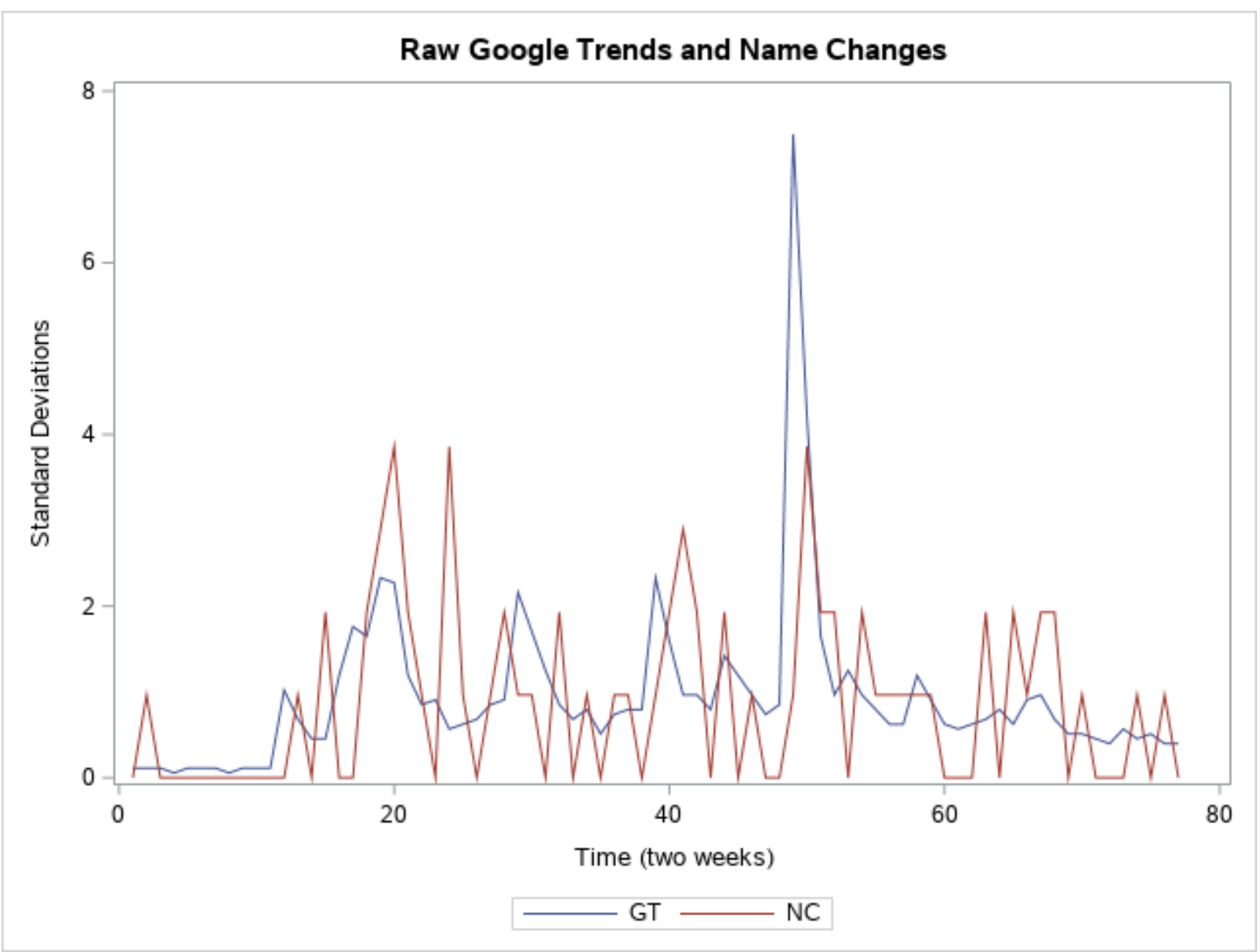

Figure 1. Line graphs of Google Trends search interest (GT) and name changes (NC). Each time series was divided by its standard deviation for comparison. The time series begin on January 5, 2014 and end on December 17, 2016.

\section{The Psychology of the Name Change Moral Panic}

In the absence of an established sociological model to describe the moral panic surrounding 'Isis' named businesses, we pose the following cognitive neoassociationistic explanation.

The media instigates the moral panic, framing ISIS as an Other that poses an existential threat to the social order. The construction of ISIS as a folk devil creates an aversive event that engenders negative affect for consumers of mass media. ISIS therefore enters the spreading-activation network of these individuals, and becomes linked with the emotional responses of the viewer, and semantically-related topics. Importantly, the spreading-activation network links the word 'Isis' itself to the terrorist group, ISIS. Through framing, the media can strengthen links to negative ideas and emotions (Boyle and Mower 2018). When these individuals encounter businesses with names containing 'Isis,' the corresponding node is activated in their spreading activation network, activating the complex of associated negative emotions and physiological reactions. Some individuals then employed controlled processing. Individuals often justified their harassment by accusing these businesses of collaborating with ISIS, among other ludicrous 
justifications (Tobitt 2015; Dare and Walker 2016; Glendinning 2014). We found no evidence that they were propagated through the media, indicating that these individuals employed rationalization to generate these accusations to justify aggression against these businesses. This cognitive neoassociationistic mechanism ultimately culminates in a hostile backlash against businesses, the physical manifestation of a moral panic.

Since cognitive neoassociation theory predicts that as negative affect increases, the stronger the instigation to action ceteris paribus, we conducted an empirical investigation to test that claim and provide hypothetico-deductive evidence for our theory using the case of these businesses. We therefore investigated the association between the magnitude of negative affect and the instigation to action, using Google Trends data on ISIS and number of name changes as proxy variables, respectively.

\section{Methods}

\section{Google Trends}

We used Google Trends data as a proxy variable for the magnitude of negative affect generated by ISIS. In a moral panic, negative affect is largely analogous to public concern; the more severe the perceived threat, the greater public concern. The use of Google Trends as a barometer of public concern is well-established (Ortiz-Martínez et al. 2020; Chen et al. 2014; Costola, Iacopini, and Santagiustina 2020; Knipe et al. 2020). Since public concern is essentially negative affect, we believe that Google Trends search data on ISIS can serve as a proxy variable for the strength of the negative affect generated by ISIS.

Data on Google Trends were collected from the publicly available website at http://www.google.com/trends. Google Trends provides a time series of the relative search volume (RSV) of a specific term or topic entered into the Google search engine over a given time period. The proportion of searches at each point for the selected term is estimated with a large random sample of all searches within the selected region at that point in time. The calculated proportions are then scaled from 0 to 100 such that 100 is the peak search interest within the entire selected time range, i.e., if the maximum proportion were 0.8 , a proportion of 0.4 would become 50 . The normalized value is the RSV. For example, a RSV value of 24 in a week-by-week time series would indicate that the proportion of searches for the selected term during that selected week was $24 \%$ of the maximum weekly proportion in the whole time range (Google n.d.b).

We used the query, 'Islamic State of Iraq and the Levant (Topic),' which includes data on all searches determined by Google to relate to ISIS; for example, searches using alternate names for the group or containing misspellings would be included (Google n.d.a). Since using specific search terms in Google Trends such as 'ISIS' may have included searches for subjects such as Isis, the Egyptian goddess, or the River Isis, we opted to use a search topic, which groups searches based on the perceived purpose of the search (Ran 2013). The search was restricted to the UK by selecting "United Kingdom" in the options bar. We selected the "Web Search" option in the options bar, which includes only searches in the Google search engine.

The two data points marked as " $<1$ ” were recorded as zero. 
The data were collected for the period from January 5, 2014 to December 17, 2016. All data were initially collected in one-week intervals and then summed into non-overlapping two-week intervals.

\section{Name Changes}

We believe that data on name changes of businesses that used to have names containing 'Isis' serves as a good barometer for the hostility expressed in this moral panic. We found ample evidence for aggressive reactions like verbal attacks, vandalism or other forms of harassment of these businesses (see hostility section), but presumably there may be less visible fear reactions, such as avoiding a business. In any case, both exert pressure on these businesses to change their names, so the trend in name changes reflects the strength of the instigations to action generated via the cognitive neoassociationistic process.

We used the Companies House database to collect data on name changes. Companies House is the national registry of companies in the UK, excluding the Crown dependencies and the British Overseas Territories. Only limited companies are required to register (Companies House 2016). Overseas companies with a physical presence in the UK are also required to register, although we encountered none (Townley 2018). All data in Companies House are based on documents filed by business owners and are not checked by Companies House for accuracy (Companies House n.d.).

We collected data on instances of businesses changing their name away from one containing "Isis." Data were collected by reviewing all search results for 'ISIS' in the free, publicly accessible Companies House Service at https://find-and-update.company-information.service.gov.uk/, which includes results for former company names. We recorded the date when the filed paperwork for a name change was processed by Companies House and legally effected. Because ISIS officially changed its name to ISIS on April 1, 2013, two earlier name changes on February 21, 1992 and October 12, 1998 were excluded (Spencer 2015).

All data were collected in two-week intervals beginning on January 5, 2014 and ending on December 17, 2016.

\section{Statistical Analysis}

All statistical analysis was performed in SAS University Edition build 9.04.01M6P110718 (SAS Institute, 100 SAS Campus Drive, Cary, NC 27513-2414, USA). An ARIMA model was applied and the residuals of the forecasts were obtained. A Spearman cross-correlation analysis was then applied to the residuals to find the cross-correlation at the optimal lag. $\rho$-values greater than 0.7 were classed as strong and $\rho$-values between 0.4 and 0.7 were classed as moderate. All statistical analysis was conducted using two-tailed $p<0.05$ as the standard for significance.

Time series almost always exhibit autocorrelation, violating the assumption of independent observations underlying many statistical techniques. Since the cross-correlation between autocorrelated time series is spurious, autocorrelation must be removed from at least one of the time series to get meaningful results (Hartmann et al. 1980). The standard procedure to remove autocorrelation is 
pre-whitening (Dean and Dunsmuir 2016). The first step in pre-whitening is to identify an ARIMA model such that the residuals of one of the time series are white noise. The same ARIMA model should then be applied to the other time series. The cross-correlation between the time series of the residuals can then be interpreted as usual.

The raw Google Trends and name change data both displayed weak serial dependence. The Phillips-Perron test indicated that both time series were already weakly stationary in their undifferenced forms, fulfilling the stationarity requirement for ARIMA. The Google Trends time series was converted into white noise with a MA(1) model and the name change time series was pre-whitened with the same model. The ARIMA model was chosen as parsimoniously as possible and according to the guidelines of Cook and Campbell (1979).

\section{Results}

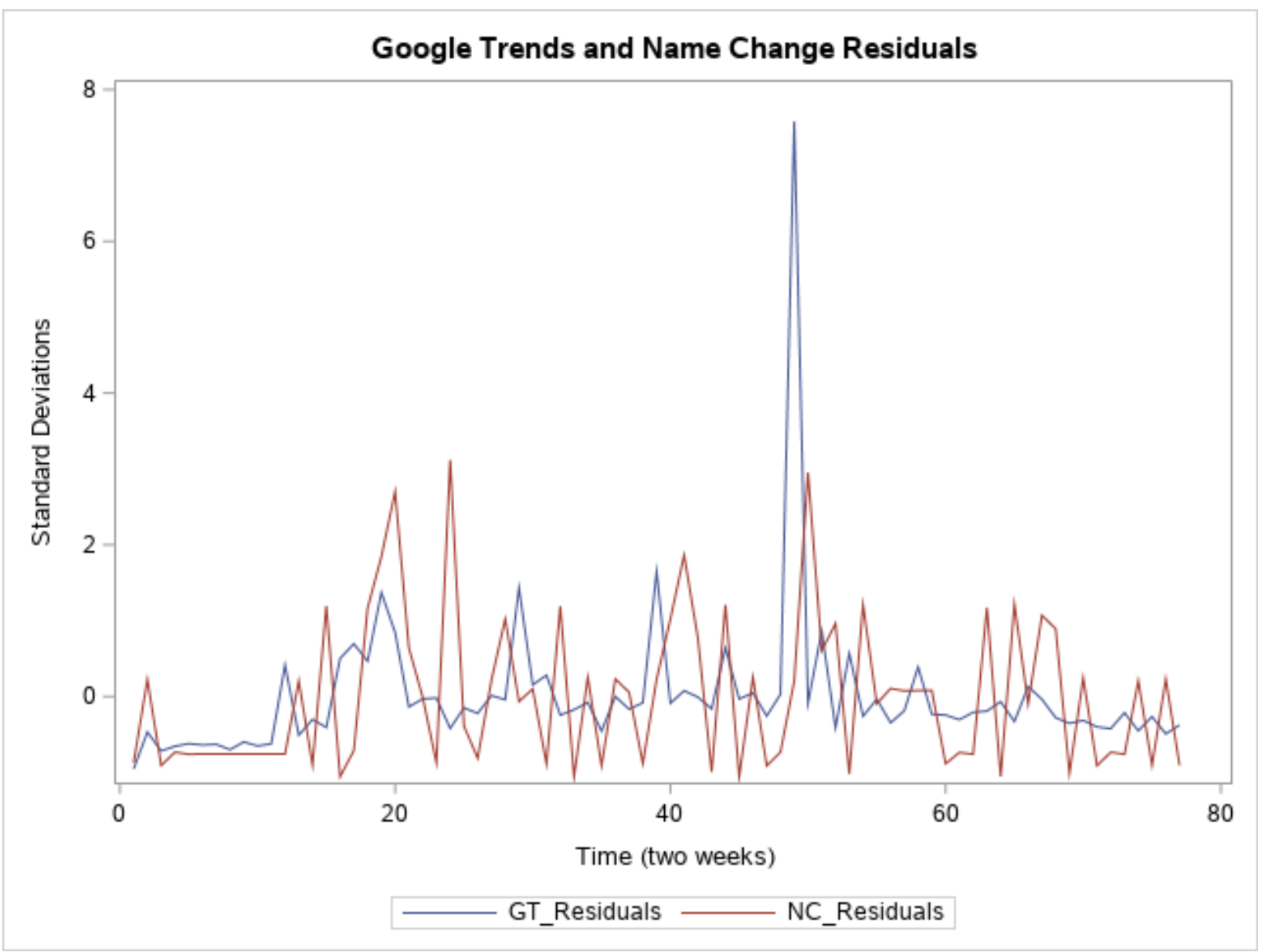

Figure 2. Line graphs of Google Trends residuals (GT_Residuals) and name change residuals (NC_Residuals). Each time series was divided by its standard deviation for ease of viewing. The time series begin on January 5, 2014 and end on December 17, 2016. 
Figure 2 documents the Google Trends and Name Change time series after pre-whitening. The Spearman cross-correlation analysis documented in Figure 3 indicates that the optimal lag is two weeks. Table 1 indicates that at the optimal lag, there is a moderate Spearman cross-correlation of approximately 0.4533 that is significant at a $p<0.01$ level.

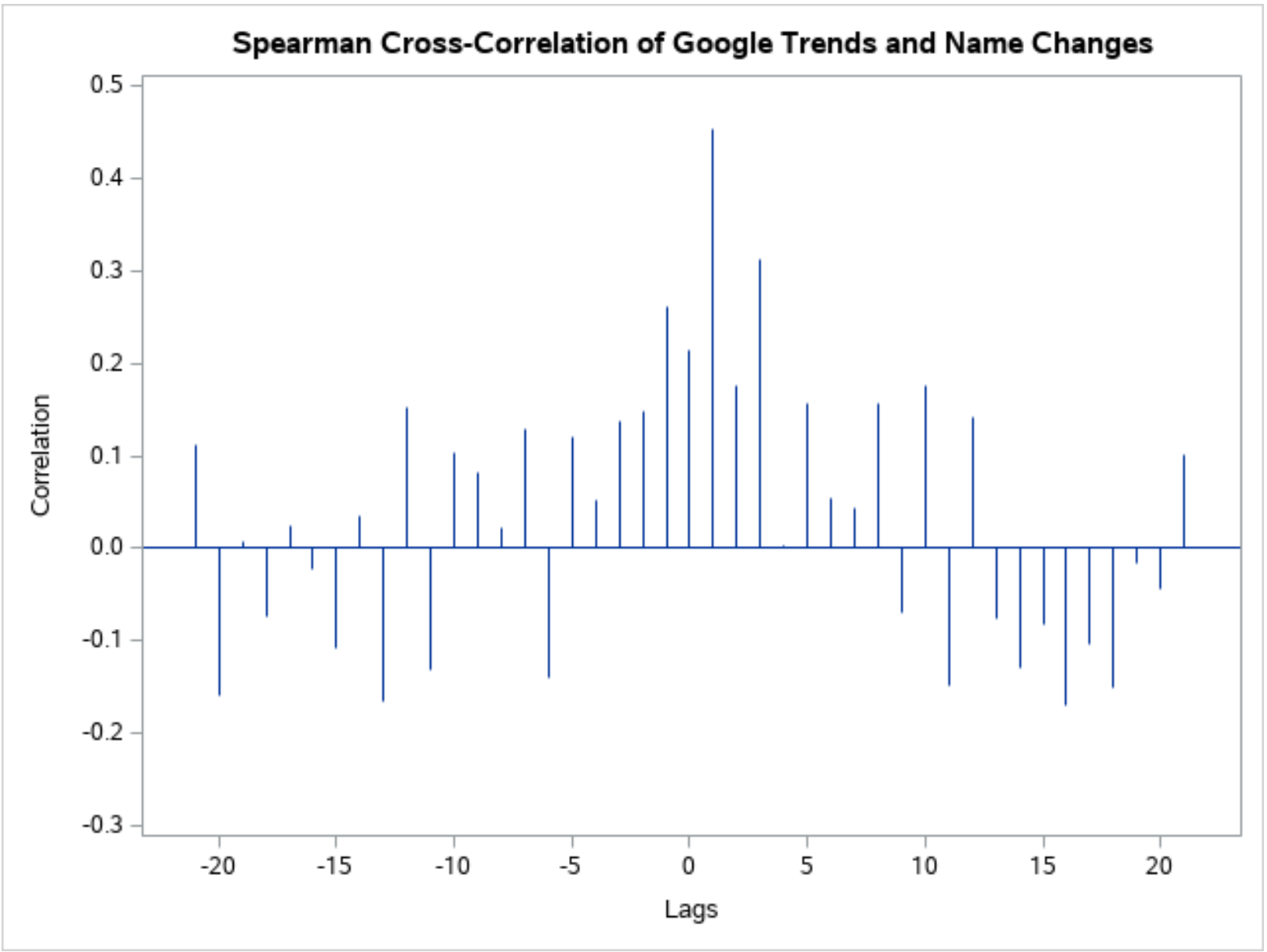

Figure 3. The Spearman cross-correlation of the Google Trends time series and name change time series by two-week lags from -22 to 22 . A positive lag indicates that the name change time series is translated backward and a negative lag indicates it is translated forward. 


\section{Google Trends}

\section{Correlation Coefficient}

$0.4533^{* *}$

Name Sig. (2-tailed) $\quad<0.01$

Changes

Lag (two weeks)

$\mathrm{N}$

\section{${ }^{\star *}$. Correlation is significant at the 0.05 level (2-tailed).}

Table 1. Spearman's $\rho$ at the optimal lag.

\section{Discussion}

Naturally, nearly all information about ISIS that UK citizens receive is disseminated by the media. Extensive research has shown that especially through framing, the media has immense power to shape public opinion and public concerns (Chong and Druckman 2007). Funkhouser (1973) even asserts that public concern about social issues is just individuals "regurgitating back to the pollster what is currently in the news" (p. 69). Even considering the potential for individuals to engage critically with the media, public concern about ISIS will be at the very least positively associated with media coverage. We have in turn empirically demonstrated that public concern is associated with the strength of the instigations to action, so we therefore have shown that the degree of media coverage is associated with the strength of the instigations to action generated in individuals. This validates a central prediction of our theoretical psychological framework in the case of these businesses.

The most unique aspect of this case is the gap between the object of the moral panic defined by the media and attacks on these businesses, which necessarily must have been caused by individual psychological processes. Established moral panic models fail to theoretically examine the role of individual psychologies in moral panics, so they are unable to account for this case. On the other hand, we have proposed that the spreading-activation network serves as the fundamental origin of instigations to 
action in moral panics. This formulation explains why individuals act against stimuli that are conceptually linked to the folk devil (e.g., during the Satanic Panic, ordinary daycare workers came under suspicion, since "daycare worker" was conceptually linked to the folk devil), but also why individuals can act when the stimuli is only linked semantically to the folk devil. In this case, the businesses share no attributes of the terrorist folk devil, so the only link is an inherent semantic link, like the links between the multiple meanings of a word. The notion of a network of associations is critical to explaining the moral panic. Therefore, our psychological framework provides a superior theoretical structure for moral panics than established theories.

Overall, this case reveals a theoretical gap in moral panic literature, and emphasizes the need to examine psychology to fully understand the moral panic. Quantitatively, our Spearman's $\rho$ of 0.4533 indicates that as negative affect increases, the strength of the instigations to action generated increases, validating a central prediction of cognitive neoassociation theory. Qualitatively, we have shown that cognitive neoassociation theory provides a full theoretical accounting of the moral panic.

\section{Limitations}

Companies House only records legal names. Some companies have a separate, unregistered, "trading name" under which they do business. Therefore, the data in this study necessarily does not include any instances where a company changed its trading name but not its legal name (Townley 2019). Companies House only registers limited companies, so our analysis does not include other types of UK businesses. The primary business structures it excludes are sole proprietorships and partnerships, which together formed $66 \%$ of the UK business population in 2016, neither of which have publicly available naming records (Department of Business, Energy and Industrial Strategy).

Beyond unambiguously aggressive harassment, we also found some limited instances in the case of these businesses in which individuals made comments or joked about the name, which cannot be readily identified as stemming from an aggressive or escape tendency generated through the cognitive neoassociationistic process, but still made business owners uncomfortable. Theoretically, some businesses could have changed their name primarily due to these comments and jokes, which would challenge our assumption that name changes data is a proxy variable for aggression. However, we did not encounter such a case and business owners generally displayed strong reluctance to rebrand due to financial considerations, even in the face of aggressive harassment, so we find it unlikely that these acts contributed significantly to the decisions of business owners to rebrand.

\section{Future Research}

A psychological perspective on moral panics opens many new theoretical possibilities. The moral panic has primarily been analyzed as a top-down phenomenon proceeding from the media while ignoring the role of individuals. However, future research taking a psychological perspective would enable an analytic framework that proceeds from a conceptualization of the moral panic as a sum of individual psychologies, and explain how individual actions create a greater social phenomenon with emergent properties, providing an alternative to prevailing top-down theories. 
Angelides has already pointed out the need to not only examine the effect of discourse on the individual, but also of the individual on discourse in moral panics (Angelides 2004). In other words, moral panics must be reconceptualized as a dynamic cycle between individuals and social attitudes, the latter primarily represented by the media, rather than a one-way causal relationship. A psychological or psychoanalytic perspective here can clarify examinations of this dynamic relationship. In terms of cognitive neoassociation theory, this relationship can be conceptualized as how individual actions affect the choices of the media, which in turn modifies negative affect. Moral panic theories ought to incorporate a psychological perspective to advance towards more dynamic theories that account for feedback relationships.

A psychological, interactionist approach to moral panics can also address prevailing concerns about the assumption of a gullible, unquestioning public. That assumption essentially takes a strict situationist approach, entirely failing to consider individual psychological differences stemming from personality. Cognitive neoassociation theory can provide a plausible explanation for the mechanism of action of personality effects, by understanding personality differences in dispositions to certain actions to be varying strengths of certain links in the spreading-activation network (Bushman 1996). Berkowitz (2011) asserted that "genetic factors, prior learning, and situational influences all enter to determine the various strengths of [fight or flight] reactions." For example, an individual with strong links leading to aggressive nodes likely has an aggressive personality and is therefore more inclined to react strongly in a moral panic.

Personality effects may also manifest during rationalization. LeBreton, Grimaldi, and Schoen (2019) has proposed that individuals employ systematically faulty, conditional reasoning, in the form of certain justification mechanisms, to justify aggression, which has been extensively validated empirically. The propensity to employ conditional reasoning, or the ability to access justification mechanisms, is a personality attribute that varies widely across individuals. Since rationalization is critical for individuals in moral panics to permit themselves to aggress, these personality differences in conditional reasoning capability likely mean that certain types of individuals are more likely to engage in aggressive action in moral panics. A personality-focused examination of moral panics may also permit research into the specific types of justification mechanisms used in various moral panics and their development. Research into the personality profiles of individuals involved in moral panics from the perspective of cognitive neoassociation theory and rationalization may prove fruitful.

\section{References}

Ahmed, Wasim, Peter A. Bath, Laura Sbaffi, and Gianluca Demartini. 2018. "Moral Panic through the Lens of Twitter." In Proceedings of the 9th International Conference on Social Media and Society, 217-21. New York, NY: Association for Computing Machinery. https://doi.org/10.1145/3217804.3217915.

Amin, Ash. 2003. "Unruly Strangers? The 2001 Urban Riots in Britain." International Journal of Urban and Regional Research 27 (2): 460-63. https://doi.org/10.1111/1468-2427.00459.

Anderson, Craig A., and Brad J. Bushman. 2002. "Human Aggression." Annual Review of Psychology 53 (1): 27-51. https://doi.org/10.1146/annurev.psych.53.100901.135231. 
Angelides, Steven. 2004. "Historicizing Affect, Psychoanalyzing History." Journal of Homosexuality 46 (1-2): 79-109. https://doi.org/10.1300/j082v46n01_02.

Bandura, Albert. 1999. "Moral Disengagement in the Perpetration of Inhumanities." Personality and Social Psychology Review 3 (3): 193-209. https://doi.org/10.1207/s15327957pspr0303_3.

Baucum, Matt, and Richard John. 2019. "Gradients of Fear and Anger in the Social Media Response to Terrorism.” In Proceedings of the 52nd Hawaii International Conference on System Sciences. Honolulu: University of Hawai'i at Mānoa 10.24251/HICSS.2019.276.

Baumeister, Roy F., Karen Dale, and Kristin L. Sommer. 1998. "Freudian Defense Mechanisms and Empirical Findings in Modern Social Psychology: Reaction Formation, Projection, Displacement, Undoing, Isolation, Sublimation, and Denial." Journal of Personality 66 (6): 1081-1124. https://doi.org/10.1111/1467-6494.00043.

Berkowitz, Leonard. 1962. Aggression: A Social Psychological Analysis. New York: Mcgraw-Hill.

Berkowitz, Leonard. 1984. "Some Effects of Thoughts on Anti- and Prosocial Influences of Media Events: A Cognitive-Neoassociation Analysis.” Psychological Bulletin 95 (3): 410-27. https://doi.org/10.1037/0033-2909.95.3.410.

Berkowitz, Leonard. 1989. "Frustration-Aggression Hypothesis: Examination and Reformulation." Psychological Bulletin 106 (1): 59-73. https://doi.org/10.1037/0033-2909.106.1.59.

Berkowitz, Leonard. 1990. "On the Formation and Regulation of Anger and Aggression: A Cognitive-Neoassociationistic Analysis.” American Psychologist 45 (4): 494-503. https://doi.org/10.1037/0003-066x.45.4.494.

Berkowitz, Leonard. 2008. "On the Consideration of Automatic as Well as Controlled Psychological Processes in Aggression.” Aggressive Behavior 34 (2): 117-29. https://doi.org/10.1002/ab.20244.

Berkowitz, Leonard. 2011. “A Cognitive-Neoassociation Theory of Aggression.” In Handbook of Theories of Social Psychology: Volume Two, edited by Paul van Lange, Arie Kruglanski, and E. Tory Higgins. SAGE Publications.

Berkowitz, Leonard, and Bartholomeu T. Troccoli. 1990. "Feelings, Direction of Attention, and Expressed Evaluations of Others." Cognition \& Emotion 4 (4): 305-25. https://doi.org/10.1080/02699939008408080.

Boyle, Kris, and Jordan Mower. 2018. "Framing Terror: A Content Analysis of Media Frames Used in Covering ISIS.” Newspaper Research Journal 39 (2): 205-19. https://doi.org/10.1177/0739532918775667.

Breuer, Johannes, and Malte Elson. 2017. "Frustration-Aggression Theory." Edited by Peter Sturmey. The Wiley Handbook of Violence and Aggression, September, 1-12. https://doi.org/10.1002/9781119057574.whbva040.

Bulman, May. 2018. "UK More Concerned about Terror than Any Other Country, Finds Study." The Independent. Available online:

https://www.independent.co.uk/news/uk/home-news/uk-terror-concerns-higher-other-countries-isi s-terrorism-attacks-study-ipsos-mori-britain-a8147691.html. (accessed on 17 January 2021).

Burgess, Melinda C. R., Karen E. Dill, S. Paul Stermer, Stephen R. Burgess, and Brian P. Brown. 2011. "Playing with Prejudice: The Prevalence and Consequences of Racial Stereotypes in Video Games.” Media Psychology 14 (3): 289-311. https://doi.org/10.1080/15213269.2011.596467. 
Bushman, Brad J. 1996. "Individual Differences in the Extent and Development of Aggressive Cognitive-Associative Networks.” Personality and Social Psychology Bulletin 22 (8): 811-19. https://doi.org/10.1177/0146167296228004.

Cameron, David. 2015. "Cameron: Combat 'appalling radical narrative' of IS.” Interview by Justin Webb. Today. London, UK: BBC Radio 4. June 29, 2015.

Carle, Jill. 2015. "Climate Change Seen as Top Global Threat: Americans, Europeans, Middle Easterners Focus on ISIS as Greatest Danger." Washington, D.C.: Pew Research Center. https://core.ac.uk/download/pdf/30671637.pdf.

Chen, Tao, Erin Pik Ki So, Liang Wu, and Isabel Kit Ming Yan. 2014. “THE 2007-2008 U.S. RECESSION: WHAT DID the REAL-TIME GOOGLE TRENDS DATA TELL the UNITED STATES?" Contemporary Economic Policy 33 (2): 395-403. https://doi.org/10.1111/coep.12074.

Chernobrov, Dmitry. 2018. "Who Is the Modern 'Traitor'? 'Fifth Column' Accusations in US and UK Politics and Media.” Politics 39 (3): 347-62. https://doi.org/10.1177/0263395718776215.

Chong, Dennis, and James N. Druckman. 2007. "Framing Theory." Annual Review of Political Science 10 (1): 103-26. https://doi.org/10.1146/annurev.polisci.10.072805.103054.

Collins, Allan M., and Elizabeth F. Loftus. 1975. "A Spreading-Activation Theory of Semantic Processing." Psychological Review 82 (6): 407-28. https://doi.org/10.1037/0033-295x.82.6.407.

Companies House. 2016. "Companies House Official Statistics : Definitions to Accompany Statistical Releases." Companies House. Available online:

https://www.gov.uk/government/publications/definitions-to-accompany-our-statistical-releases/co mpanies-house-official-statistics-definitions-to-accompany-statistical-releases. (accessed 29 December 2020).

Companies House. n.d. "Service Information.” Companies House. Available online: http://resources.companieshouse.gov.uk/serviceInformation.shtml. (accessed 3 January 2021).

Cook, Thomas D., and D. T. Campbell. 1979. Quasi-Experimentation: Design and Analysis Issues for Field Settings. Boston, MA: Houghton Mifflin.

Costola, Michele, Matteo Iacopini, and Carlo Romano Marcello Alessandro Santagiustina. 2020. "Public Concern and the Financial Markets during the COVID-19 Outbreak." SSRN Electronic Journal. https://doi.org/10.2139/ssrn.3591193.

Critcher, Chas. 2009. "Widening the Focus: Moral Panics as Moral Regulation.” British Journal of Criminology 49 (1): 17-34. https://doi.org/10.1093/bjc/azn040.

Critcher, Chas. 2017. "Moral Panics." In Oxford Research Encyclopedia of Criminology and Criminal Justice. Oxford University Press. https://doi.org/10.1093/acrefore/9780190264079.013.155.

Dare, Tom, and Marc Walker. 2016. "Essex Salon Called ISIS Changes Name after Bizarre Threat from 'Head of ISIS."” Daily Mirror. Available online: https://www.mirror.co.uk/news/uk-news/essex-hair-salon-called-isis-9363442. (accessed 2 February 2021.)

Dean, Roger T., and William T. M. Dunsmuir. 2015. "Dangers and Uses of Cross-Correlation in Analyzing Time Series in Perception, Performance, Movement, and Neuroscience: The Importance of Constructing Transfer Function Autoregressive Models.” Behavior Research Methods 48 (2): 783-802. https://doi.org/10.3758/s13428-015-0611-2.

Devine, Patricia G. 1989. "Stereotypes and Prejudice: Their Automatic and Controlled Components." Journal of Personality and Social Psychology 56 (1): 5-18. https://doi.org/10.1037/0022-3514.56.1.5. 
de Waal, Joel Rogers. 2014. "Report on British Attitudes to Defence, Security and the Armed Forces | YouGov.” YouGov. October 25, 2014.

https:/yougov.co.uk/topics/international/articles-reports/2014/10/25/report-british-attitudes-defen ce-security-and-arme.

Dollard, John, Neal E. Miller, Leonard W. Doob, O. H. Mowrer, and Robert R. Sears. 1939. Frustration and Aggression. New Haven: Yale University Press. https://doi.org/10.1037/10022-000.

Enoch, Nick. 2013. "Rebels Behead Assad's Thugs in Front of Children.” Daily Mail. Available online: https://www.dailymail.co.uk/news/article-2420263/Syrian-civil-war-rebels-behead-Assads-thugschildren-really-sides.html. (accessed 15 February 2021).

European Commission. 2017. "Standard Eurobarometer 87 - Spring 2017." European Commission. August 2017. Standard Eurobarometer 87 - Spring 2017 - August 2017 - - Eurobarometer survey (europa.eu)

Express. 2016. "Terrified Hairdresser Forced to Change Name from Isis after Being Bombarded with Threats." Daily Express. Available online: https://www.express.co.uk/news/uk/738191/Isis-terrorism-hairdressers-salon-name-change-threat s-bombarded. (accessed 2 March 2021).

Falkof, Nicky. 2012. “'Satan Has Come to Rietfontein': Race in South Africa’s Satanic Panic.” Journal of Southern African Studies 38 (4): 753-67. https://doi.org/10.1080/03057070.2012.732290.

Falkof, Nicky. 2018. “On Moral Panic: Some Directions for Further Development." Critical Sociology 46 (2): 225-39. https://doi.org/10.1177/0896920518803698.

Frost, Brian C., Chia-Huei Emily Ko, and Lawrence R. James. 2007. "Implicit and Explicit Personality: A Test of a Channeling Hypothesis for Aggressive Behavior." Journal of Applied Psychology 92 (5): 1299-1319. https://doi.org/10.1037/0021-9010.92.5.1299.

Funkhouser, G. Ray. 1973. "The Issues of the Sixties: An Exploratory Study in the Dynamics of Public Opinion.” Public Opinion Quarterly 37 (1): 62. https://doi.org/10.1086/268060.

Garland, David. 2008. "On the Concept of Moral Panic." Crime, Media, Culture: An International Journal 4 (1): 9-30. https://doi.org/10.1177/1741659007087270.

Gilman, Sander L. 2010. “Moral Panic and Pandemics.” The Lancet 375 (9729): 1866-67. https://doi.org/10.1016/s0140-6736(10)60862-8.

Glendinning, Amy. 2014. "Cafe Named Isis Forced to Change Its Name over Fears of Being Linked to Terrorist Group.” Manchester Evening News. Available online:

https://www.manchestereveningnews.co.uk/news/greater-manchester-news/cafe-named-isis-force d-change-7918393. (accessed 18 June 2021).

Goode, Erich, and Nachman Ben-Yehuda. 1994. "Moral Panics: Culture, Politics, and Social Construction." Annual Review of Sociology 20 (1): 149-71. https://doi.org/10.1146/annurev.so.20.080194.001053.

Goode, Erich, and Nachman Ben-Yehuda. 2009. Moral Panics: The Social Construction of Deviance. 2nd ed. John Wiley \& Sons.

Google. n.d.a "Compare Trends Search Terms." Google. Available online: https://support.google.com/trends/answer/4359550. (accessed 16 April 2021).

Google. n.d.b "FAQ about Google Trends Data." Google. https://support.google.com/trends/answer/4365533?hl=en. (accessed 17 April 2021).

Hamed, Gahad. 2017. "Radicalism and the Practice of Violence in the Muslim World." The Canadian Journal for Middle East Studies 2 (1): 93-108. https://cjmes.scholasticahq.com/article/2090.pdf. 
Hartmann, Donald P., John M. Gottman, Richard R. Jones, William Gardner, Alan E. Kazdin, and Russell S. Vaught. 1980. "Interrupted Time-Series Analysis and Its Application to Behavioral Data." Journal of Applied Behavior Analysis 13 (4): 543-59. https://doi.org/10.1901/jaba.1980.13-543.

Hier, Sean P. 2008. "Thinking beyond Moral Panic: Risk, Responsibility, and the Politics of Moralization." Theoretical Criminology 12 (2): 173-90. https://doi.org/10.1177/1362480608089239.

Hughes, Sarah. 2017. “American Monsters: Tabloid Media and the Satanic Panic, 1970-2000.” Journal of American Studies 51 (3): 691-719. https://doi.org/10.1017/s0021875816001298.

Jewkes, Yvonne. 2015. Media and Crime. 3rd ed. Thousand Oaks: SAGE Publications.

Josephson, Wendy L. 1983. "The Effects of Violent Television upon Children's Aggression: Elicitation, Disinhibition, or Catharsis?" Ph.D. dissertation, University of Manitoba.

Kelley, Stephanie. 2015. "Fighting Words: How Media Coverage of ISIS Endangers Public Consciousness." The Oxonian Globalist. Available online: http://toglobalist.org/2015/02/fighting-words-how-media-coverage-of-isis-endangers-public-cons ciousness/. (accessed 5 April 2021).

Kennedy, Bruce. 2014. "Private Equity Firm Isis Seeks a New Name." CBS News. Available online: https://www.cbsnews.com/news/private-equity-firm-isis-seeks-a-new-name/. (accessed 18 July 2021).

Kirk, Ashley. 2017. "How Many People Are Killed by Terrorist Attacks in the UK?” The Telegraph. Available online: https://www.telegraph.co.uk/news/0/many-people-killed-terrorist-attacks-uk/. (accessed 18 March 2021).

Knipe, Duleeka, Hannah Evans, Mark Sinyor, Thomas Niederkrotenthaler, David Gunnell, and Ann John. 2020. "Tracking Online Searches for Emotional Wellbeing Concerns and Coping Strategies in the UK during the COVID-19 Pandemic: A Google Trends Analysis." Wellcome Open Research 5 (September): 220. https://doi.org/10.12688/wellcomeopenres.16147.1.

Krinsky, Charles, ed. 2008. Moral Panics over Contemporary Children and Youth. Farnham, UK: Ashgate Publishing.

LeBreton, James M., Elizabeth M. Grimaldi, and Jeremy L. Schoen. 2019. "Conditional Reasoning: A Review and Suggestions for Future Test Development and Validation." Organizational Research Methods 23 (1): 65-95. https://doi.org/10.1177/1094428118816366.

Miller, N. E. 1941. "I. The Frustration-Aggression Hypothesis.” Psychological Review 48 (4): 337-42. https://doi.org/10.1037/h0055861.

Moore, Keith. 2004. "Bodgies, Widgies and Moral Panic in Australia 1955-1959." In Social Change in the 21st Century: 2004 Conference Proceedings.

Newsroom. 2017. "Harborough Salon Finally Changes Its ISIS Name after Unwanted Attention." Harborough Mail. Available online: https:/www.harboroughmail.co.uk/news/harborough-salon-finally-changes-its-isis-name-after-un wanted-attention-745643. (accessed 7 January 2021).

Office for National Statistics. 2020. "Deaths registered in England and Wales: 2019." Office for National Statistics. July 1, 2020.

Ortiz-Martínez, Yeimer, Juan Esteban Garcia-Robledo, Danna L. Vásquez-Castañeda, D. Katterine Bonilla-Aldana, and Alfonso J. Rodriguez-Morales. 2020. "Can Google® Trends Predict COVID-19 Incidence and Help Preparedness? The Situation in Colombia.” Travel Medicine and Infectious Disease, April, 101703. https://doi.org/10.1016/j.tmaid.2020.101703. 
Pargeter, Alison. 2015. "The Rise of ISIS and Islamophobia in the UK." https://studies.aljazeera.net/sites/default/files/articles/reports/documents/201582473554630734ISI S.pdf.

Pearce, Julia M, and Elizabeth Charman. 2011. "A Social Psychological Approach to Understanding Moral Panic.” Crime, Media, Culture: An International Journal 7 (3): 293-311. https://doi.org/10.1177/1741659011417607.

Poushter, Jacob, and Dorothy Manevich. 2017. "Globally, People Point to ISIS and Climate Change as Leading Security Threats: Concern about Cyberattacks, World Economy Also Widespread." Washington, D.C.: Pew Research Center. https:/www.pewglobal.org/wp-content/uploads/sites/2/2017/07/Pew-Research-Center_2017.07.1 3_Global-Threats_Full-Report.pdf.

Poynting, Scott, Greg Noble, and Paul Tabar. 2001. "Middle Eastern Appearances: 'Ethnic Gangs', Moral Panic and Media Framing.” Australian \& New Zealand Journal of Criminology 34 (1): 67-90. https://doi.org/10.1177/000486580103400105.

Quillian, M. Ross. 1967. "Word Concepts: A Theory and Simulation of Some Basic Semantic Capabilities." Behavioral Science 12 (5): 410-30. https://doi.org/10.1002/bs.3830120511.

Ran, Gil. 2013. "An Easier Way to Explore Topics and Entities in Google Trends." Google. December 3, 2013. https://search.googleblog.com/2013/12/an-easier-way-to-explore-topics-and.html.

Rowe, Laurel, and Gray Cavender. 1991. “Caldrons Bubble, Satan's Trouble, but Witches Are Okay: Media Constructions of Satanism and Witchcraft.” In The Satanism Scare, edited by James T. Richardson, Joel Best, and David G. Bromley. New York: Transaction Publishers.

RT. “'Brand Suicide': Companies Sharing Name with ISIS Forced to Rebrand.” 2014. RT. Available online: https://www.rt.com/news/186216-isis-brand-name-companies/. (accessed 29 May 2021).

Scapens, Alex. 2014. "Spiritual Shop Abused for Sharing Name with Terror Group ISIS." Manchester Evening News. Available online:

https://www.manchestereveningnews.co.uk/news/greater-manchester-news/its-making-things-ver y-difficult-7841404. (accessed 2 May 2021).

Scroll Staff. 2016. “Oxford's Isis Academy Changes Name to Avoid Confusion.” Scroll.in. Available online: https://scroll.in/latest/803305/oxfords-isis-academy-changes-name-to-avoid-confusion. (accessed 16 May 2021).

Shafir, Gershon, and Cynthia E. Schairer. 2013. "The War on Terror as Political Moral Panic.” In Lessons and Legacies of the War on Terror: From Moral Panic to Permanent War, edited by Gershon Shafir, Everard Meade, and William J. Aceves. London, UK: Routledge.

Shammas, John. 2016. "Hairdressing Salon Called ISIS Forced to Change Its Name after Threatening Email." The Sun. Available online: https://www.thesun.co.uk/news/2297420/village-hairdressing-salon-called-isis-forced-to-change-i ts-name-after-threatening-email-claiming-to-be-from-terror-chief/. (accessed 4 June 2021).

Simmel, Georg. (1908) 1964. Conflict \& the Web of Group-Affiliations. Translated by Kurt H. Wolff and Reinhard Bendix. New York: Free Press. https://archive.org/details/conflicts00simm.

Smith, Matthew. 2016. "Terrorist attack in Britain expected by $84 \%$ of people." YouGov. Available online: https://yougov.co.uk/topics/politics/articles-reports/2016/08/04/terrorist-attack-britain-expected-8 4-people. (accessed 8 April 2021).

Spencer, Robert. 2015. The Complete Infidel's Guide to ISIS. Washington, D.C.: Regnery Publishing. 
Sullivan, Nicola. 2014. "ISIS Recruitment Forced to Rebrand | Recruiter." Recruiter. Available online: https://www.recruiter.co.uk/news/2014/10/isis-recruitment-forced-rebrand. (accessed 17 April 2021).

Thornham, Sue, and Tony Purvis. 2005. Television Drama: Theories and Identities. London: Palgrave Macmillan.

Tobitt, Charlotte. 2015. "Isis Beauty Academy Forced to Change Name after Abusive Phone Calls, Heckling and Social Media Targeting." SurreyLive. Available online:

https://www.getsurrey.co.uk/news/surrey-news/isis-beauty-academy-forced-change-10508786. (accessed 19 April 2021).

Tomlinson, Lucas Y. 2017. "ISIS has lost 98 percent of its territory -- mostly since Trump took office, officials say." Fox News.

Available online:

https://www.foxnews.com/politics/isis-has-lost-98-percent-of-its-territory-mostly-si

nce-trump-took-office-officials-say. (accessed 4 June 2021).

Townley, Gary. 2018. "Registering an Overseas Company - Companies House." Companies House.

Available online:

https://companieshouse.blog.gov.uk/2018/05/24/registering-an-overseas-company/. (accessed 16 June 2021).

Vinogradov, Sophia, Roy J. King, and Bernardo A. Huberman. 1992. "An Associationist Model of the Paranoid Process: Application of Phase Transitions in Spreading Activation Networks."

Psychiatry 55 (1): 79-94. https://doi.org/10.1080/00332747.1992.11024582.

Walby, Kevin, and Dale Spencer. 2011. "How Emotions Matter to Moral Panics." In Moral Panic and the Politics of Anxiety, edited by Sean Hier. New York: Routledge.

Walsh, James P. 2016. "Moral Panics by Design: The Case of Terrorism." Current Sociology 65 (5): 643-62. https://doi.org/10.1177/0011392116633257.

YouGov. 2015. "Iraq, Syria and ISIS Trackers.” YouGov. July 6, 2015.

http://d25d2506sfb94s.cloudfront.net/cumulus_uploads/document/wsvj5e0sy0/YG-Archives-PolIraq-Syria-and-ISIS-101014.pdf 